DOI: $10.19195 / 2084-5065.39 .7$

\title{
Wykonywanie kary pozbawienia wolności w trzech systemach - uwagi krytyczne
}

\author{
BARBARA STAŃDO-KAWECKA
}

Zakład Prawa Karnego Wykonawczego

Wydział Prawa i Administracji Uniwersytetu Jagiellońskiego

I. Typologia zakładów karnych

i systemy wykonywania kary pozbawienia wolności

W wydawnictwach encyklopedycznych i słownikowych ,system” definiowany jest jako skoordynowany układ wzajemnie powiązanych i zależnych od siebie elementów, tworzący pewną odrębną całość, uwarunkowaną stałym, logicznym uporządkowaniem jego części składowych ${ }^{1}$. Termin ,system wykonywania kary pozbawienia wolności” w szerszym znaczeniu jest synonimem pojęcia ,system penitencjarny” i oznacza całokształt przepisów, instytucji, środków i zasad ich stosowania, które służą realizacji zadań przypisywanych karze pozbawienia wolności ${ }^{2}$. Przewidując trzy odrębne systemy wykonywania kary pozbawienia wolności w ramach polskiego systemu penitencjarnego, ustawodawca w Kodeksie

1 Encyklopedia podręczna, Kraków 2000, s. 922; Słownik wyrazów obcych PWN, Warszawa 1980, s. 723.

2 Szerzej na temat systemów penitencjarnych por. m.in. J. Śliwowski, Prawo i polityka penitencjarna, Warszawa 1982, s. 83 n.; B. Stańdo-Kawecka, Prawne podstawy resocjalizacji, Kraków 2000, s. 69 n. 
karnym wykonawczym z 1997 r. (dalej także: k.k.w.) ${ }^{3}$ użył tego terminu w innym, znacznie węższym znaczeniu. System wykonywania kary pozbawienia wolności w rozumieniu Kodeksu karnego wykonawczego nie jest synonimem systemu penitencjarnego, ale jednym z jego elementów.

Zgodnie z Kodeksem karnym wykonawczym z 1997 r. kara pozbawienia wolności wykonywana jest w zakładach karnych różnego rodzaju i typu, a ponadto w różnych systemach. Wśród rodzajów zakładów karnych art. 69 k.k.w. wymienia:

a) zakłady karne dla młodocianych,

b) zakłady karne dla odbywających karę po raz pierwszy,

c) zakłady karne dla recydywistów penitencjarnych,

d) zakłady karne dla odbywających karę aresztu wojskowego.

Artykuł 70 § 1 k.k.w. przewiduje, że każdy z tych rodzajów zakładów karnych może być organizowany jako:

a) zakład karny typu zamkniętego,

b) zakład karny typu półotwartego,

c) zakład karny typu otwartego.

Choć w literaturze naukowej można spotkać się z krytyczną oceną utrzymywania odrębnego zakładu karnego dla odbywających karę aresztu wojskowego ${ }^{4}$ oraz pewnych kryteriów stosowanych przy kierowaniu skazanych do zakładów karnych określonego rodzaju lub typu ${ }^{5}$, to potrzeba funkcjonowania zróżnicowanych na rodzaje i typy zakładów karnych nie budzi wątpliwości. Wynika ona z faktu, że w populacji skazanych odbywających karę pozbawienia wolności w zakładach karnych znajdują się

3 Ustawa z dnia 6 czerwca 1997 r. — Kodeks karny wykonawczy, Dz.U. Nr 90, poz. 557 z późn. zm.

4 Na potrzebę rozważenia de lege ferenda celowości utrzymywania w strukturze zakładów karnych zakładu dla odbywających karę aresztu wojskowego ze względu na jednostkowe przypadki odbywania tej kary przez skazanych zwraca uwagę S. Lelental, Kodeks karny wykonawczy. Komentarz, Warszawa 2014, s. 754.

5 Por. np. zastrzeżenia odnośnie uwzględniania rodzaju popełnionego przestępstwa wśród kryteriów klasyfikacji skazanych, (ibidem, s. 278) oraz krytyczną ocenę przepisów zmienionych po wejściu w życie Kodeksu karnego wykonawczego z 1997 r., dotyczących kierowania skazanych do zakładów karnych określonego rodzaju i typu (A. Nawój-Śleszyński, Indywidualizacja wykonywania kary pozbawienia wolności w kontekście zmian Kodeksu karnego wykonawczego w latach 2009-2014, [w:] Zmiany w prawie karnym wykonawczym w latach 2009-2014, red. A. Kwieciński, Warszawa 2014, s. 120 n.). 
osoby różniące się od siebie pod wieloma względami, m.in. takimi jak: płeć, wiek, wykształcenie, doświadczenie zawodowe, sytuacja rodzinna, motywy i okoliczności popełnionego przestępstwa, liczba uprzednio popełnionych przestępstw, liczba uprzednich pobytów w zakładach karnych, poziom inteligencji, kompetencje społeczne, postawy i style myślenia, stan zdrowia fizycznego i psychicznego, uzależnienia czy stopień zagrożenia stwarzanego dla innych na terenie zakładu i dla społeczeństwa. Trudno odmówić racji S. Lelentalowi, który zauważył, że racjonalnie pomyślany system penitencjarny, nastawiony na realizację określonych celów kary pozbawienia wolności, nie może pomijać problematyki związanej z klasyfikacją skazanych i typologią zakładów karnych ${ }^{6}$. Podział skazanych na grupy klasyfikacyjne i kierowanie ich do zakładów karnych odpowiedniego rodzaju i typu są istotne zarówno dla zapobiegania ich wzajemnej demoralizacji i prowadzenia skutecznych oddziaływań zmierzających do ułatwienia im integracji społecznej po opuszczeniu zakładu karnego, jak i dla zapewnienia bezpieczeństwa w zakładzie karnym oraz ochrony społeczeństwa ${ }^{7}$.

Oprócz podziału zakładów karnych na typy i rodzaje Kodeks karny wykonawczy z 1997 r. (art. 81) wprowadził trzy systemy wykonywania kary pozbawienia wolności:

a) system terapeutyczny,

b) system programowanego oddziaływania,

c) system zwykły.

Autorzy prac poświęconych problemom wykonywania kary pozbawienia wolności niejednokrotnie zajmowali się systemem programowanego oddziaływania i systemem terapeutycznym, formułując uwagi dotyczące prawnej regulacji tych systemów lub ich funkcjonowania w praktyce ${ }^{8}$. Sama koncepcja wykonywania kary pozbawienia wolności

6 S. Lelental, Prawo karne wykonawcze, Warszawa 1990, s. 103.

7 Z. Hołda, K. Postulski, Kodeks karny wykonawczy. Komentarz, Gdańsk 2005, s. 344; Kodeks karny wykonawczy. Komentarz, red. J. Lachowski, Warszawa 2015, s. 360 n.

8 Por. np. E. Habzda-Siwek, Wybrane problemy realizacji systemu terapeutycznego wykonywania kary pozbawienia wolności w polskim systemie penitencjarnym, [w:] Problemy penologii i praw człowieka na poczatku XXI stulecia. Księga poświęcona pamięci Profesora Zbigniewa Hołdy, red. B. Stańdo-Kawecka, K. Krajewski, Warszawa 2011, s. 369 n.; J. Konikowska-Kuczyńska, Wykonywanie kary pozbawienia wolności w systemie terapeutycznym wobec skazanych uzależionych od środków odurzajacych lub sub- 
w trzech różnych systemach jak dotąd nie została poddana pogłębionej analizie, pomimo upływu kilkunastu lat od wprowadzenia jej do praktyki penitencjarnej ${ }^{9}$. Celem niniejszego opracowania jest zwrócenie uwagi na pomijany dotąd problem sprowadzający się do pytania, czy idea trzech różnych systemów wykonywania kary pozbawienia wolności, uznawana w czasie prac nad projektem obowiązującego obecnie Kodeksu karnego wykonawczego za istotną dla osiagnięcia zakładanych celów wykonywania tej kary ${ }^{10}$, spełniła pokładane w niej nadzieje. W dalszej części artykułu przedstawiona zostanie geneza zróżnicowanych systemów wykonywania kary pozbawienia wolności, a następnie kontrowersyjne aspekty tego rozwiązania, jakie ujawniły się w czasie obowiązywania Kodeksu karnego wykonawczego z 1997 r.

\section{Geneza zróżnicowanych systemów wykonywania kary pozbawienia wolności}

Indywidualizacja wykonywania kary pozbawienia wolności, która obejmuje m.in. kierowanie skazanych do różnych zakładów karnych, uznawana była za jedną z podstawowych zasad polskiego systemu penitencjarnego zarówno $\mathrm{w}$ okresie międzywojennym ${ }^{11}$, jak i w czasie prac

stancji psychotropowych, Warszawa 2015; A. Nawój, Wykonywanie kary pozbawienia wolności w systemie programowanego oddziaływania, Łódź 2007; P. Stępniak, System programowanego oddziaływania w opiniach więźniów, „Archiwum Kryminologii” 2009, t. XXXI, s. 265 n.; G.B. Szczygieł, System programowego oddziaływania wykonywania kary pozbawienia wolności, [w:] Nauki penalne wobec problemów wspótczesnej przestępczości. Księga jubileuszowa z okazji 70. rocznicy urodzin Profesora Andrzeja Gaberle, red. K. Krajewski, Warszawa 2007, s. 365 n.

9 O pewnych aspektach wykonywania kary pozbawienia wolności w różnych systemach krytycznie pisze P. Stępniak, Polemicznie o systemach wykonania kary pozbawienia wolności w świetle Europejskich Regut Więziennych i doświadczeń francuskich, [w:] Modernizowanie więziennictwa. V Kongres Penitencjarny, red. T. Bulenda, A. Rzepliński, Warszawa 2015, s. 595 n.

10 Uzasadnienie rzadowego projektu nowego kodeksu karnego wykonawczego, [w:] Nowe kodeksy karne — z 1997 r. z uzasadnieniami, Warszawa 1997, s. 545 n.

11 Na temat podziału więzień na zwykłe i specjalne przewidzianego w ustawie o organizacji więziennictwa z 1939 r. por. T. Szymanowski, J. Migdał, Prawo karne wykonawcze i polityka penitencjarna, Warszawa 2014, s. 226 n. 
nad Kodeksem karnym wykonawczym z 1969 r. ${ }^{12}$, choć z biegiem czasu zmieniały się rodzaje zakładów karnychi kryteria klasyfikacji skazanych. Kodeks karny wykonawczy z 1969 r., będący pierwszą kodyfikacją prawa karnego wykonawczego w Polsce, oprócz podziału zakładów karnych ${ }^{13}$ przewidywał różne rygory wykonywania kary pozbawienia wolności. Na podstawie art. 40 tego kodeksu kara pozbawienia wolności wykonywana była według rygoru zasadniczego, złagodzonego albo obostrzonego $^{14}$. Rygor wykonywania kary wyznaczał zakres nałożonych na skazanego obowiązków i udzielonych mu uprawnień w odniesieniu do swobody poruszania się po terenie zakładu karnego, wysokości przypadającej mu części należności za pracę, komunikowania się z osobami z zewnątrz, dokonywania zakupu przedmiotów powszechnego użytku czy stosowania określonych kar dyscyplinarnych. Różnicowanie rygorów wykonywania kary pozbawienia wolności powodowało stopniowanie jej dolegliwości. Zdaniem S. Paweli obostrzanie lub łagodzenie dolegliwości kary pozbawienia wolności w odniesieniu do określonych kategorii skazanych służyło racjonalnej indywidualizacji kary i zmierzało do stworzenia możliwie najlepszych warunków do oddziaływania penitencjarnego ${ }^{15}$.

Koncepcja stopniowania dolegliwości wykonywanej kary pozbawienia wolności przez utrzymywanie różnych rygorów dla różnych grup skazanych zyskała popularność w latach sześćdziesiątych ubiegłego wie-

12 O podziale zakładów karnych w Kodeksie karnym wykonawczym z 1969 r. piszą m.in.: S. Pawela, Kodeks karny wykonawczy. Komentarz, Białystok 1994, s. 174 n.; J. Śliwowski, op. cit., s. 142 n.; A. Tobis, Prawo penitencjarne i polityka penitencjarna, Poznań 1978, s. 43 n.

13 Zgodnie z art. 39 § 1 k.k.w. z 1969 r. zakłady karne dzieliły się na: ośrodki pracy, zakłady karne zwykłe, zakłady karne przejściowe, zakłady karne dla młodocianych, zakłady karne dla recydywistów, zakłady karne dla skazanych wymagających stosowania szczególnych środków leczniczo-wychowawczych, zakłady karne dla odbywających karę aresztu wojskowego. Ten sam artykuł w § 2 upoważniał Ministra Sprawiedliwości do tworzenia w drodze rozporządzenia zakładów karnych odmiennego typu niż wymienione $\mathrm{w} \S 1$.

14 Zarządzeniem Ministra Sprawiedliwości z dnia 25 stycznia 1974 r. w sprawie tymczasowego regulaminu wykonywania kary pozbawienia wolności wprowadzono kolejny rygor, określony jako surowy. Krytycznie na temat wprowadzenia tego rygoru pisze J. Śliwowski, Tymczasowy regulamin wykonywania kary pozbawienia wolności i jego ocena, „Państwo i Prawo” 1976, z. 10, s. 38.

15 S. Pawela, op. cit., s. 188; podobnie A. Tobis, op. cit., s. 45. 
ku w kontekście walki z recydywą. Jak wyjaśnia J. Górski, wysoki odsetek recydywistów w populacji więziennej skłaniał ówczesne władze do poszukiwania bardziej skutecznych sposobów ograniczania powrotności do przestępstwa. Możliwości ograniczenia recydywy upatrywano wówczas w nasileniu surowości kary pozbawienia wolności wykonywanej wobec sprawców wielokrotnie powracających do przestępstwa. Zwiększenie surowości wykonywanej kary miało dotyczyć także sprawców przestępstw gospodarczych i przestępstw kryminalnych uznanych za groźne dla społeczeństwa ${ }^{16}$. Takie podejście do ograniczania recydywy i zwalczania przestępczości uznanej za szczególnie groźną znalazło wyraz w regulaminie wykonywania kary pozbawienia wolności z 1966 r., który był ,spełnieniem oczekiwań osób dostrzegających w represji zasadniczy środek mogący powściagnąć groźnych i niepoprawnych kryminalistów od działalności przestępczej”'17. Zróżnicowane rygory wykonywania kary pozbawienia wolności przewidziane w Kodeksie karnym wykonawczym z 1969 r. stanowiły kontynuację tej koncepcji zwalczania i ograniczania przestępczości. W okresie obowiązywania tego kodeksu podkreślano znaczenie zasady jedności prawa karnego materialnego i wykonawczego ${ }^{18}$, w której doszukiwano się uzasadnienia do tego, by orzekaniu wobec pewnych kategorii przestępców surowych kar towarzyszyły surowe warunki ich wykonywania ${ }^{19}$. W miarę upływu czasu oraz

16 J. Górski, Niektóre problemy recydywy, [w:] Rozwój penitencjarystyki w PRL. Wybrane problemy, red. P. Wierzbicki, Warszawa 1988, s. 162 n.

17 Ibidem, s. 163.

18 Zasada ta określana była także jako zasada realizacji w postępowaniu wykonawczym celów i funkcji kary, zasada ciagłości orzecznictwa lub zasada kontynuacji podstawowych rozwiązań prawa karnego materialnego w procesie wykonania kary. Szerzej na ten temat pisze S. Pawela, op. cit., s. 13 n.

19 Por. uchwałę składu 7 sędziów SN (OSNKW 1973, poz. 151) wpisaną do księgi zasad prawnych, przywołaną przez Z. Ćwiąkalskiego (Z. Ćwiąkalski, Komentarz do art. 82, [w:] Komentarz do kodeksu karnego. Część ogólna, red. K. Buchała, Warszawa 1994, s. 431), która przewidywała, że w stosunku do sprawców prowadzących pasożytniczy tryb życia, skazanych na karę pozbawienia wolności, sądy orzekające powinny rozważyć potrzebę rozstrzygnięcia już w wyroku skazującym o wykonaniu kary w odpowiednim zakładzie karnym. W przypadku sprawców, którzy powrócili do pasożytniczego trybu życia i przestępstwa, powinno to z reguły oznaczać orzeczenie zaostrzonego rygoru wykonywania kary. 
zmian sytuacji politycznej i społecznej zróżnicowane rygory wykonywania kary pozbawienia wolności stawały się przedmiotem coraz silniejszej krytyki w nauce prawa karnego wykonawczego.

Pod koniec lat osiemdziesiatych ubiegłego wieku jednoznacznie negatywną ocenę rygorów wykonywania kary pozbawienia wolności wyraził T. Szymanowski. Jego zdaniem zwiększanie dolegliwości wykonywanej kary pozbawienia wolności nie tylko nie spełniło nadziei na obniżenie powrotności do przestępstwa, ale nawet przyniosło efekty przeciwne do oczekiwanych. Rygory, jak zauważył autor odwołujący się do wyników badań empirycznych, nasilały negatywne zachowania skazanych w czasie odbywania kary pozbawienia wolności i wpływały na wzrost recydywy po opuszczeniu zakładu karnego ${ }^{20}$. Ostatecznie w Kodeksie karnym wykonawczym z 1997 r. rygory wykonywania kary pozbawienia wolności przewidziane w poprzednim kodeksie zostały zastapione przez systemy wykonywania tej kary ${ }^{21}$. Wykonywanie kary pozbawienia wolności w trzech różnych systemach (programowanego oddziaływania, terapeutycznym i zwykłym) w założeniach twórców Kodeksu karnego wykonawczego z 1997 r. miało sprzyjać realizacji zasady indywidualizacji oraz osiagnięciu indywidualnoprewencyjnego celu tej kary w przeciwieństwie do dawnych rygorów, którym ,nadawano bezzasadnie walory czynnika oddziałującego resocjalizacyjnie na skazanych, poprzez stopniowanie dolegliwości i ograniczeń"22.

Dyskusje nad reformą polskiego systemu penitencjarnego, jakie toczyły się na przełomie lat osiemdziesiątych i dziewięćdziesiątych XX wieku, wskazują zatem na to, że jednym z zasadniczych powodów wprowadzenia trzech różnych systemów wykonywania kary pozbawienia wolności było dążenie do wyeliminowania i zastąpienia zróżnicowanych rygorów wykonywania tej kary. Wśród innych powodów przemawiających za różnymi systemami wykonywania kary pozbawienia wolności należy wymienić nieskuteczność przymusowych oddziały-

20 T. Szymanowski, Stan aktualny i postulowane kierunki rozwoju systemu penitencjarnego w Polsce, [w:] Doświadczenia i perspektywy systemu penitencjarnego w Polsce, red. T. Szymanowski, A. Rzepliński, Warszawa 1987, s. 49.

21 T. Szymanowski, Z. Świda, Kodeks karny wykonawczy. Komentarz, Warszawa 1998, s. 175.

22 Ibidem. 
wań resocjalizacyjnych i terapeutycznych, realizowanych w zakładach karnych, oraz dążenie do odrzucenia przymusu resocjalizacji motywowane poszanowaniem praw skazanych i ich podmiotowości. Wynika to z uzasadnienia rządowego projektu Kodeksu karnego wykonawczego z 1997 r., w którym stwierdzono, że dotychczasowe efekty oddziaływań resocjalizacyjnych i terapeutycznych podejmowanych wobec skazanych w zakładach karnych nie odpowiadały oczekiwaniom, a rozwój idei poszanowania praw więźniów postawił pod znakiem zapytania przymus resocjalizacji ${ }^{23}$. W świetle tego uzasadnienia ustawodawca za podstawowy cel wykonywania kary pozbawienia wolności uznał prewencję szczególną, a jednocześnie przyjął, że oddziaływanie resocjalizacyjne stosowane wobec skazanego w zasadzie powinno stać się jego uprawnieniem lub ofertą ze strony organu wykonującego, z której nie musi on skorzystać ${ }^{24}$. Zdaniem ustawodawcy za odrzuceniem przymusu resocjalizacji przemawiały zarówno względy aksjologiczne (koncepcja poszanowania prawa człowieka do decydowania o sobie), jak i pragmatyczne. Te ostatnie związane były z przekonaniem, że ,efektywne jest takie zwłaszcza oddziaływanie na dorosłego człowieka, które on sam zaakceptuje, i jako jego podmiot nawiąże współdziałanie z wychowawcami, nauczycielami, terapeutami itd." 25 .

\section{Kontrowersyjne aspekty zróżnicowanych systemów wykonywania kary pozbawienia wolności}

Od chwili wejścia w życie Kodeks karny wykonawczy z 1997 r. był wielokrotnie nowelizowany. Jeśli jednak chodzi o przepisy regulujące wykonywanie kary pozbawienia wolności w trzech różnych systemach, to wprowadzone zmiany miały ograniczony charakter i nie naruszały zasadniczej koncepcji wypracowanej w toku prac nad tym kodeksem. Szczegółowa analiza zasad wykonywania kary pozbawienia wolności w trzech różnych systemach w ramach tego artykułu nie jest możliwa,

${ }^{23}$ Uzasadnienie rzqdowego projektu..., s. 545.

24 Ibidem.

25 Ibidem, s. 546. 
ale nie jest także niezbędna do tego, by wskazać kilka najbardziej kontrowersyjnych aspektów przyjętych rozwiązań.

Terapeutyczny system wykonywania kary pozbawienia wolności, podobnie jak przewidywał Kodeks karny wykonawczy z 1997 r. w swoim pierwotnym brzmieniu, nadal przeznaczony jest dla skazanych, którzy z powodu niepełnosprawności fizycznej, niepsychotycznych zaburzeń psychicznych $^{26}$, upośledzenia umysłowego, uzależnienia od alkoholu albo innych środków odurzających lub psychotropowych wymagają oddziaływania specjalistycznego, zwłaszcza opieki psychologicznej, lekarskiej lub rehabilitacyjnej (art. $96 \S 1$ k.k.w.). Skierowanie skazanego do terapeutycznego systemu wykonywania kary nie wymaga jego zgody. Leczenie i rehabilitacja skazanego w zasadzie wymagają jego zgody, ale art. 117 k.k.w. przewiduje od tej zasady wyjątki. Dotyczą one skazanych, u których stwierdzono uzależnienie od alkoholu albo środków odurzających lub substancji psychotropowych, a także skazanych za wymienione $\mathrm{w}$ tym przepisie przestępstwa seksualne popełnione w związku z zaburzeniami preferencji seksualnych. $\mathrm{W}$ przypadku tych skazanych $\mathrm{w}$ razie braku ich zgody o stosowaniu leczenia lub rehabilitacji orzeka sąd penitencjarny.

W Kodeksie karnym wykonawczym z 1997 r. ustawodawca zrezygnował z wyodrębnienia zakładów karnych dla skazanych wymagających oddziaływania specjalistycznego, a w szczególności opieki psychologicznej, lekarskiej lub rehabilitacyjnej. W pierwotnym brzmieniu tego kodeksu nie określił także, czy wykonywanie kary pozbawienia wolności w systemie terapeutycznym ma być realizowane na terenie każdego zakładu karnego, czy jedynie w wydzielonych oddziałach, utworzonych specjalnie do tego celu. Na mocy nowelizacji z $2003 \mathrm{r}^{27}$ do art. 96 k.k.w. dodano $\S 4$ przewidujący, że karę pozbawienia wolności w systemie terapeutycznym wykonuje się przede wszystkim w oddziale terapeutycznym o określonej specjalizacji, nie wykluczając jednak możliwości wykonywania tej kary w systemie terapeutycznym poza oddziałem terapeutycz-

${ }^{26}$ Kategoria skazanych z niepsychotycznymi zaburzeniami psychicznymi obecnie obejmuje także skazanych za określone przestępstwa seksualne popełnione w związku z zaburzeniami preferencji seksualnych (art. 96 § 1 k.k.w.).

27 Ustawa z dnia 24 lipca 2003 r. o zmianie ustawy - Kodeks karny wykonawczy oraz niektórych innych ustaw, Dz.U. z 2003 r. Nr 142, poz. 1380. 
nym. Obecnie wśród oddziałów terapeutycznych znajdują się oddziały dla skazanych:

a) z niepsychotycznymi zaburzeniami psychicznymi lub upośledzonych umysłowo,

b) uzależnionych od alkoholu,

c) uzależnionych od środków odurzających lub substancji psychotropowych,

d) niepełnosprawnych fizycznie ${ }^{28}$.

Analiza danych statystycznych dotyczących liczby skazanych odbywających karę pozbawienia wolności w systemie terapeutycznym na oddziale terapeutycznym i poza takim oddziałem prowadzi do interesujących wniosków. W ostatnich latach, w okresie od grudnia 2011 r. do czerwca 2015 r., liczba skazanych przebywających w oddziałach terapeutycznych o różnej specjalizacji była dość stabilna i wahała się pomiędzy 2,927 i 3,062 (wykres 1). W tym samym czasie wyraźnie zmniejszyła się liczba skazanych zakwalifikowanych do oddziałów terapeutycznych, którzy $\mathrm{z}$ różnych powodów ${ }^{29}$ przebywali poza tymi oddziałami. O ile w ostatnim dniu 2011 r. poza oddziałami terapeutycznymi przebywało 1,205 skazanych zakwalifikowanych do takich oddziałów, to 30 czerwca 2015 r. było ich 768. Jednocześnie w latach 2011-2015 liczba skazanych zakwalifikowanych do systemu terapeutycznego poza oddziałem terapeutycznym wzrosła z 1 do 870 .

Szybki wzrost ilości skazanych zakwalifikowanych do systemu terapeutycznego poza oddziałem terapeutycznym nieprzypadkowo zbiegł się w czasie ze zmianą rozporządzenia Ministra Sprawiedliwości w sprawie sposobów prowadzenia oddziaływań penitencjarnych w zakładach karnych i aresztach śledczych, która weszła w życie 14 stycznia 2013 r. $^{30}$

28 Por. § 15 rozporządzenia Ministra Sprawiedliwości z dnia 14 sierpnia 2003 r. w sprawie sposobów prowadzenia oddziaływań penitencjarnych w zakładach karnych i aresztach śledczych, Dz.U. z 2003 r. Nr 151, poz. 1469 z późn. zm.

29 W informacji statystycznej (rocznej i kwartalnej) Centralnego Zarządu Służby Więziennej przyczyny przebywania skazanych zakwalifikowanych do oddziałów terapeutycznych poza tymi oddziałami kategoryzowane są w następujący sposób: leczenie, II sprawy, oczekiwanie na transport, inne.

30 Rozporządzenie Ministra Sprawiedliwości z dnia 26 listopada 2012 r. zmieniające rozporządzenie w sprawie sposobów prowadzenia oddziaływań penitencjarnych w za- 
Skazani w systemie terapeutycznym

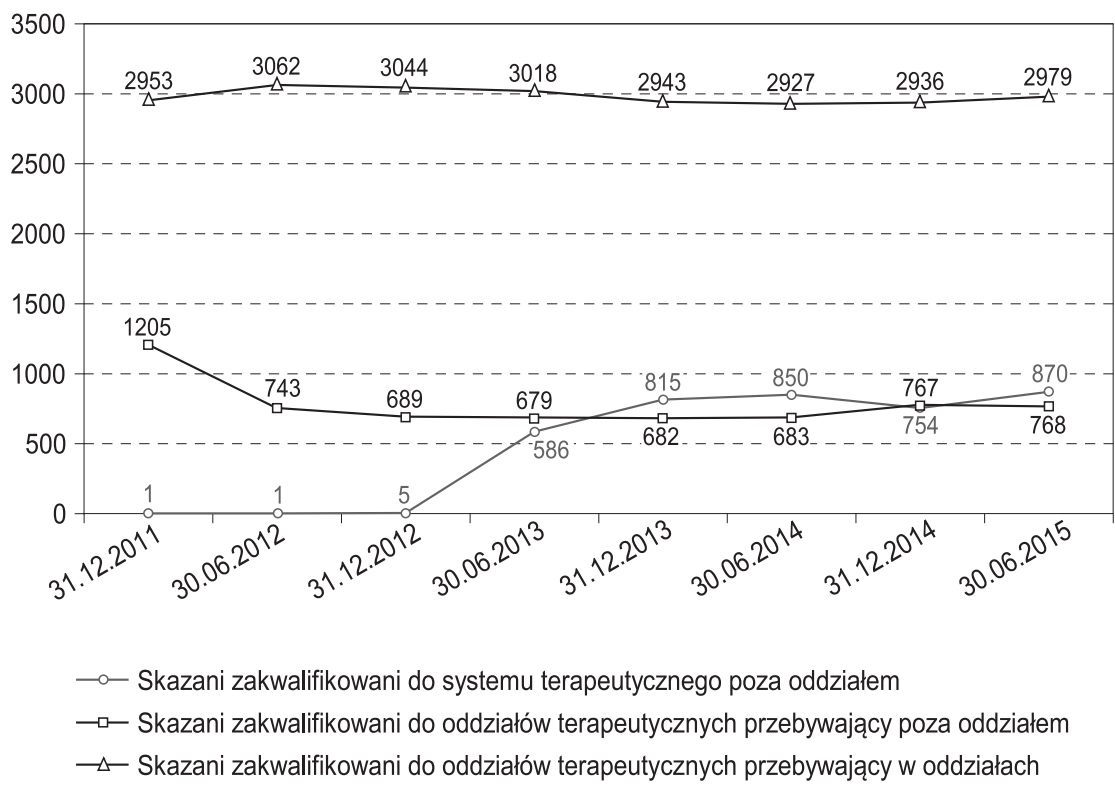

Wykres 1. Skazani skierowani do terapeutycznego systemu wykonywania kary pozbawienia wolności w latach 2011-2015

Źródło: dane statystyczne według rocznej i kwartalnej informacji statystycznej Centralnego Zarządu Służby Więziennej dostępnej w Internecie: www.sw.gov.pl (dostęp: 3.01.2016).

W zmienionym rozporządzeniu uregulowano stosowanie wobec skazanego uzależnionego, który został skierowany do systemu terapeutycznego poza oddziałem terapeutycznym, krótkiej interwencji lub terapii krótkoterminowej. Zgodnie z § 21 ust. 2 rozporządzenia po nowelizacji krótka interwencja składa się z co najmniej 3 sesji. Program takiej interwencji obligatoryjnie obejmuje ocenę stopnia nasilenia problemów wynikających z uzależnienia, przekazanie skazanemu informacji zwrotnej o wyniku oceny, rozmowę motywującą go do podjęcia terapii lub samodzielnej zmiany oraz przekazanie mu odpowiednich wskazówek dotyczących zmiany zachowań wynikających z uzależnienia. W odróżnieniu od krótkiej interwencji, na terapię krótkoterminową składa się co naj-

kładach karnych i aresztach śledczych, Dz.U. z 2012 r., poz. 1409.

Nowa Kodyfikacja Prawa Karnego 39, 2016

(C) for this edition by CNS 
mniej 10 sesji, wśród których mieści się program krótkiej interwencji a ponadto analiza funkcjonalna zachowań skazanego, ćwiczenie umiejętności zaradczych i zapobieganie nawrotom.

Skazani uzależnieni, którzy zostali skierowani do odbywania kary w systemie terapeutycznym poza oddziałem terapeutycznym, po okresie odbywania kary w tym systemie poza oddziałem mogą być skierowani do oddziału terapeutycznego, jeżeli jest to uzasadnione zmianą ich sytuacji lub względami terapeutycznymi. Jeśli nie występują przesłanki uzasadniające skierowanie do oddziału terapeutycznego, skazany uzależniony po krótkiej interwencji lub terapii krótkoterminowej może zostać przeniesiony do systemu zwykłego albo — przy spełnieniu określonych warunków - do systemu programowanego oddziaływania. Jednak bez względu na to, czy po okresie pobytu w systemie terapeutycznym poza oddziałem skazany uzależniony ostatecznie trafi na oddział terapeutyczny, pojawia się pytanie, czy działania informacyjno-edukacyjne dotyczące problemów wynikających z uzależnienia, motywowanie skazanych do podjęcia terapii lub samodzielnej zmiany oraz ćwiczenie umiejętności zaradczych wymaga kierowania ich do terapeutycznego systemu wykonywania kary pozbawienia wolności. Jak dotąd brak jest dowodów na to, że wydawanie decyzji o skierowaniu skazanego uzależnionego do systemu terapeutycznego poza oddziałem terapeutycznym ma pozytywny wpływ na poziom jego zaangażowania i zwiększa skuteczność działań podejmowanych w ramach krótkiej interwencji lub terapii krótkoterminowej.

Odbywanie kary pozbawienia wolności w systemie terapeutycznym poza oddziałem terapeutycznym od dawna krytykowane jest przez praktyków więziennictwa i przedstawicieli nauki prawa karnego wykonawczego $^{31}$. Jak zauważył A. Kwieciński, zadania realizowane w ramach systemu terapeutycznego poza oddziałem terapeutycznym mogą być prowadzone w systemie programowanego oddziaływania ${ }^{32}$. Możliwość realizacji systemu terapeutycznego poza oddziałem terapeutycznym, zdaniem autora, powinna być poddana wnikliwej analizie, ponieważ ,niejasny charakter tej formuły i potencjalne ryzyko nadużywania

31 Por. A. Kwieciński, Skazani z niepsychotycznymi zaburzeniami psychicznymi, [w:] Postępowanie z wybranymi grupami skazanych w polskim systemie penitencjarnym. Aspekty prawne, red. A. Kwieciński, Warszawa 2013, s. 169 i lit. tam cytowana.

32 Ibidem, s. 170. 
jej w zależności od potrzeb administracji więziennej przemawiają za jej likwidacją"33. Kierowanie skazanych do systemu terapeutycznego, a następnie podejmowanie decyzji o przeniesieniu ich do innego systemu wykonywania kary pozbawienia wolności po to, aby w trakcie kilku czy kilkunastu sesji edukować ich w zakresie problemów wynikających z uzależnienia i motywować do podjęcia terapii, wydaje się być nadużyciem, którego obawiał się A. Kwieciński.

Można wskazać wiele istotnych powodów przemawiających za tworzeniem i utrzymywaniem oddziałów terapeutycznych w zakładach karnych. W przypadku skazanych z zaburzeniami psychicznymi i niepełnosprawnych, którzy wymagają oddziaływania specjalistycznego, a w szczególności opieki psychologicznej, lekarskiej lub rehabilitacyjnej, takim powodem jest spoczywający na władzach państwowych obowiązek poszanowania godności osób pozbawionych wolności i zapewnienia im ochrony zdrowia psychicznego i fizycznego. Zaburzenia psychiczne i uzależnienia są czynnikami zwiększającymi ryzyko powrotności do przestępstwa i jest to kolejny powód do prowadzenia oddziaływań specjalistycznych umożliwiających ograniczenie tego ryzyka i ułatwienie skazanemu integracji społecznej po opuszczeniu zakładu karnego. Z doświadczeń polskiego więziennictwa wynika, że wśród skazanych wykazujących zaburzenia psychiczne, upośledzonych umysłowo i uzależnionych znajduje się spora grupa osób, które nie potrafią przystosować się do zwykłych warunków życia w zakładzie karnym. Bez specjalistycznych oddziaływań prowadzonych w oddziałach terapeutycznych stanowią oni zagrożenie dla siebie lub dla innych i powodują poważne trudności w utrzymaniu porządku i bezpieczeństwa w zakładzie karnym ${ }^{34}$.

Po kilkunastu latach funkcjonowania oddziałów terapeutycznych pod rządami Kodeksu karnego wykonawczego z 1997 r. zachodzi jednak potrzeba pogłębionej dyskusji na temat kierowania skazanych do takich oddziałów. Na uwagę zasługuje wysuwany w nauce prawa karnego wykonawczego postulat ograniczenia kierowania skazanych do syste-

33 Ibidem, s. 171-172.

34 Ibidem, s. 150 n.; por. także B. Stańdo-Kawecka, Badania osobopoznawcze skazanych $i$ oddziaływania terapeutyczne $w$ historii rozwoju więziennictwa, [w:] Psychologia i prawo. Między teoria a praktyka, red. E. Habzda-Siwek, J. Kabzińska, Sopot 2014, s. $441 \mathrm{n}$. 
mu terapeutycznego bez ich zgody do tych wypadków, w których jest to uzasadnione zagrożeniem, jakie ze względu na swój stan zdrowia lub niepełnosprawność stwarzają dla siebie, współwięźniów lub personelu ${ }^{35}$. Kolejnym problemem wymagającym dyskusji jest pytanie o skuteczne sposoby motywowania skazanych do terapii. W szerszej perspektywie rozważenia wymaga kwestia celowości utrzymywania zróżnicowanych systemów wykonywania kary pozbawienia wolności. Do refleksji nad tym ostatnim zagadnieniem zachęcają nie tylko wątpliwości dotyczące odbywania kary w systemie terapeutycznym poza oddziałem terapeutycznym, ale także doświadczenia związane z jej wykonywaniem w systemach programowanego oddziaływania i zwykłym.

Skazani, którzy nie spełniają przesłanek uzasadniających skierowanie ich do systemu terapeutycznego, odbywają karę pozbawienia wolności w systemie programowanego oddziaływania albo zwykłym. Istotą odbywania przez skazanego kary w systemie programowanego oddziaływania jest realizacja programu indywidualnego oddziaływania. Program indywidualnego oddziaływania ujmowany jest w nauce prawa karnego wykonawczego jako pochodząca od zakładu karnego oferta pomocy skazanemu, który podejmie decyzję o zmianie swoich postaw ${ }^{36}$. W art. 95 $\S 2$ k.k.w. ustawodawca niewyczerpująco wskazuje elementy składowe programu oddziaływania. Zgodnie z treścią tego przepisu, w programie oddziaływania ustala się zwłaszcza:

a) rodzaje zatrudnienia i nauczania skazanych,

b) kontakty skazanych przede wszystkim z rodziną i innymi osobami bliskimi,

c) wykorzystywanie czasu wolnego,

d) możliwości wywiązywania się przez skazanych z ciążących na nich obowiązków, oraz

e) inne przedsięwzięcia niezbędne dla przygotowania skazanych do powrotu do społeczeństwa.

Skazani młodociani odbywają karę pozbawienia wolności w systemie programowanego oddziaływania bez względu na to, czy wyrazili zgodę na udział w opracowaniu i realizacji programu oddziaływania (art.

35 A. Kwieciński, op. cit., s. 171.

36 G.B. Szczygieł, op. cit., s. 365. 
$95 \S 1$ k.k.w.). Wyjątek stanowią skazani młodociani odbywający zastępczą karę pozbawienia wolności oraz młodociani, którzy zostali ukarani karą aresztu za wykroczenie lub karą porządkową, oraz ci, wobec których zastosowano środki przymusu skutkujące pozbawieniem wolności; zgodnie z art. 99 k.k.w. wymienione wyżej kary i środki wykonywane są w systemie zwykłym, jeżeli nie zachodzą szczególne względy przemawiające za skierowaniem do innego systemu. Te same przepisy dotyczące odbywania w systemie zwykłym zastępczej kary pozbawienia wolności, kary aresztu, kar porządkowych i środków przymusu skutkujących pozbawienie wolności mają zastosowanie do skazanych dorosłych. Pomijając te wyjątki, w przypadku skazanych dorosłych niewymagających umieszczenia w systemie terapeutycznym jest zasada, że mogą oni dokonać wyboru pomiędzy odbywaniem kary w systemie zwykłym albo w systemie programowanego oddziaływania. Karę pozbawienia wolności w systemie programowanego oddziaływania skazani dorośli odbywają wtedy, kiedy po przedstawieniu im projektu programu oddziaływania wyrażają zgodę na współudział w opracowaniu takiego programu i jego realizacji (art. $95 \S 1$ k.k.w.).

Uzasadnienie rządowego projektu Kodeksu karnego wykonawczego wskazuje na to, że pozostawienie możliwości wyboru pomiędzy systemem zwykłym i systemem programowanego oddziaływania skazanym dorosłym, którzy nie wymagają specjalistycznego oddziaływania realizowanego w systemie terapeutycznym, motywowane było dążeniem do odrzucenia przymusu resocjalizacji i przekonaniem o większej skuteczności oddziaływań zaakceptowanych przez skazanego ${ }^{37}$. Jak wynika z tego uzasadnienia, a także z pierwszego komentarza do Kodeksu karnego wykonawczego z 1997 r., z systemem programowanego oddziaływania wiązano duże nadzieje na poprawę skuteczności oddziaływań prowadzonych w zakładach karnych. Zdaniem T. Szymanowskiego i Z. Świdy system programowanego oddziaływania miał być podstawowym sposobem wykonywania kary pozbawienia wolności, który jednocześnie będzie najpełniej służył resocjalizacji rozumianej jako zmiana postaw skazanych przez ugruntowanie społecznie akceptowanego systemu wartości, a ponadto umożliwi skazanym zdobycie umiejętności niezbędnych do po-

${ }^{37}$ Uzasadnienie rzadowego projektu..., s. 546. 
myślnej readaptacji społecznej po zwolnieniu z zakładu karnego ${ }^{38}$. Znaczenie systemu programowanego oddziaływania miało polegać na tym, że będzie on stanowił, ,rzeczywistą szansę dla osób pragnących zmienić swój sposób życia" 39 . Jednocześnie autorzy zakładali, że w praktyce penitencjarnej najważniejszym zadaniem będzie objęcie systemem programowanego oddziaływania przede wszystkim skazanych młodocianych i recydywistów, a ponadto tych nierecydywistów, którzy wykazują wyraźne symptomy nieprzystosowania społecznego ${ }^{40}$.

Nadzieje i oczekiwania, że system programowanego oddziaływania pozwoli najpełniej realizować cel wykonywania kary pozbawienia wolności zakreślony w art. $67 \S 1$ k.k.w. ${ }^{41}$, przesunęły na drugi plan pytanie o to, na czym w istocie polegają różnice pomiędzy odbywaniem kary pozbawienia wolności w tym systemie i w systemie zwykłym. Nie ulega przecież wątpliwości, że ustawodawca w art. $67 \S 1$ k.k.w. przewiduje ten sam cel wykonywania kary pozbawienia wolności dla skazanych odbywających karę w różnych systemach. Do realizacji tego celu zobowiązani są funkcjonariusze Służby Więziennej i pracownicy zakładu, którzy zgodnie z art. $78 \S 1$ k.k.w. wykonują karę pozbawienia wolności w zakładzie karnym, bez względu na to, w jakim systemie skazany tę karę odbywa. Należy także zwrócić uwagę na to, że obowiązki administracji zakładu karnego, wynikające z przepisów Kodeksu karnego wykonawczego regulujących przygotowanie skazanego do zwolnienia ${ }^{42}$, dotyczą wszystkich skazanych niezależnie od systemu, w jakim odbywają oni karę. Ustawodawca w art. $95 \S 2$ k.k.w. wskazuje, że rodzaje zatrudnienia i nauczania skazanych, ich kontakty z rodziną i innymi osobami bliskimi, wykorzystywanie czasu wolnego, możliwości wywiązywania się z ciążących na nich obowiązków oraz inne przedsięwzięcia niezbędne dla przy-

38 T. Szymanowski, Z. Świda, op. cit., s. 217.

39 Ibidem, s. 218.

40 Ibidem.

${ }^{41}$ Zgodnie z art. 67 § 1 k.k.w. wykonywanie kary pozbawienia wolności ma na celu wzbudzanie w skazanym woli współdziałania w kształtowaniu jego społecznie pożądanych postaw, w szczególności poczucia odpowiedzialności oraz potrzeby przestrzegania porządku prawnego, i tym samym powstrzymania się od powrotu od przestępstwa.

42 Por. Rozdział X Kara pozbawienia wolności, Oddział 12 Zwalnianie skazanych z zakładów karnych i warunki udzielania im pomocy Kodeksu karnego wykonawczego z $1997 \mathrm{r}$. 
gotowania ich do powrotu do społeczeństwa stanowią podstawowe elementy programu indywidualnego oddziaływania. Jednak przepisy tego artykułu nie dają podstaw do zaniechania przedsięwzięć niezbędnych dla przygotowania do powrotu do społeczeństwa tych skazanych, którzy odbywają karę w systemie zwykłym.

Skazani odbywający karę pozbawienia wolności w systemie zwykłym mogą korzystać z dostępnego w zakładzie karnym zatrudnienia, nauczania oraz zajęć kulturalno-oświatowych i sportowych (art. 98 k.k.w.). Podobnie jak skazani odbywający karę w systemie programowanego oddziaływania, także ci odbywający karę w systemie zwykłym mają obowiązek wykonywania pracy (art. $116 \S 1$ pkt 4 k.k.w.) oraz pierwszeństwo w zapewnieniu im pracy, jeżeli są zobowiązani do świadczeń alimentacyjnych lub mają szczególnie trudną sytuację materialną, osobistą lub rodzinną (art. $122 \S 2$ k.k.w.). Podjęcie nauki w zakładzie karnym jest obowiązkiem skazanego, który nie ukończył 18 roku życia. Skazani, którzy nie ukończyli 18 lat, należą do grupy młodocianych, którzy z nielicznymi wyjątkami odbywają karę pozbawienia wolności w systemie programowanego oddziaływania. Jeśli chodzi o skazanych dorosłych, to nie mają oni obowiązku nauki, ale zarówno ci odbywający karę w systemie programowanego oddziaływania, jak i ci odbywający karę w systemie zwykłym mogą korzystać z nauczania dostępnego w zakładzie karnym. Zgodnie z art. 130 § 3 k.k.w. pierwszeństwo w uzyskaniu możliwości objęcia nauczaniem w szkole ponadpodstawowej (ponadgimnazjalnej) i na kursach zawodowych mają nie tylko skazani, którzy nie ukończyli 21 roku życia, ale także ci, którzy nie mają wyuczonego zawodu albo po odbyciu kary nie będą mogli go wykonywać. Odbywanie kary pozbawienia wolności w systemie zwykłym nie tylko nie wyklucza uczestniczenia w nauczaniu prowadzonym w zakładzie karnym, ale także nie przekreśla pierwszeństwa przy klasyfikowaniu skazanych do nauczania, jeśli spełniają oni odpowiednie przesłanki. Należałoby dodać, że utrzymywanie więzi z rodziną i innymi osobami bliskimi, kształcenie, samokształcenie i wykonywanie twórczości własnej oraz korzystanie z urządzeń i zajęć kulturalno-oświatowych i sportowych należy do praw skazanych, przysługujących im niezależnie od systemu wykonywania kary pozbawienia wolności (art. 102 k.k.w.). 
Analiza przepisów Kodeksu karnego wykonawczego, regulujących wykonywanie kary pozbawienia wolności, prowadzi do wniosku, że ustawodawca przewidział stosowanie tych samych środków oddziaływania penitencjarnego wobec skazanych odbywających tę karę w systemie zwykłym i programowanego oddziaływania. Istotną różnicę pomiędzy odbywaniem kary pozbawienia wolności w obydwu systemach miało stanowić planowanie oddziaływań w odpowiedniej sekwencji w odniesieniu do skazanych skierowanych do systemu programowanego oddziaływania. Przy ograniczonym dostępie skazanych do pracy, a szczególnie pracy odpłatnej, a także do nauczania i kształcenia zawodowego, konstruowanie programów indywidualnego oddziaływania w praktyce nie jest łatwe. $\mathrm{Z}$ badań sondażowych wynika, że niekiedy jako zadania przewidziane do realizacji w ramach takich programów traktuje się uprawnienia skazanych lub ciążące na nich obowiązki, np. ,utrzymywanie systematycznych kontaktów z rodziną”, „czynne uczestniczenie w zajęciach kulturalno-oświatowych”, ,poprawne zachowywanie się" lub ,zgodne współżycie z innymi osadzonymi i funkcjonariuszami"43. Dane statystyczne wskazują na to, że największy odsetek skazanych odbywających karę pozbawienia wolności w systemie zwykłym jest wśród recydywistów penitencjarnych, a zatem w grupie skazanych, u których występują liczne obszary problemowe zwiększające ryzyko recydywy (wykres 2).

Po kilkunastu latach obowiązywania Kodeksu karnego wykonawczego z 1997 r. praktyka znacząco odbiega od oczekiwania, że system programowanego oddziaływania oprócz skazanych młodocianych obejmie przede wszystkim recydywistów. Wobec braku badań empirycznych trudno ocenić, czy spośród skazanych nierecydywistów w systemie programowanego oddziaływania odbywają karę pozbawienia wolności przede wszystkim ci, którzy wykazują wyraźne symptomy nieprzystosowania społecznego, jak zakładali to T. Szymanowski i Z. Świda pod koniec lat dziewięćdziesiątych ubiegłego wieku ${ }^{44}$. Nie można wykluczyć, że spośród dorosłych nierecydywistów system programowanego oddziaływania

43 J. Zagórski, Indywidualizacja penitencjarna w postępowaniu ze skazanymi - na przykładzie skazanych młodocianych oraz odbywajacych kare dożywotniego pozbawienia wolności, [w:] Prawo karne wykonawcze w systemie nauk kryminologicznych. Księga pamiatkowa ku czci Profesora Leszka Boguni, red. T. Kalisz, Wrocław 2011, s. 283.

44 T. Szymanowski, Z. Świda, op. cit., s. 218. 
najczęściej wybierają skazani, w przypadku których zachodzi niewielkie ryzyko popełnienia kolejnego przestępstwa, natomiast planowanie i sekwencyjne realizowanie zaplanowanych oddziaływań nie dotyczy nierecydywistów z ,wyraźnymi symptomami nieprzystosowania społecznego".

Skazani i ukarani według systemu wykonywania kary

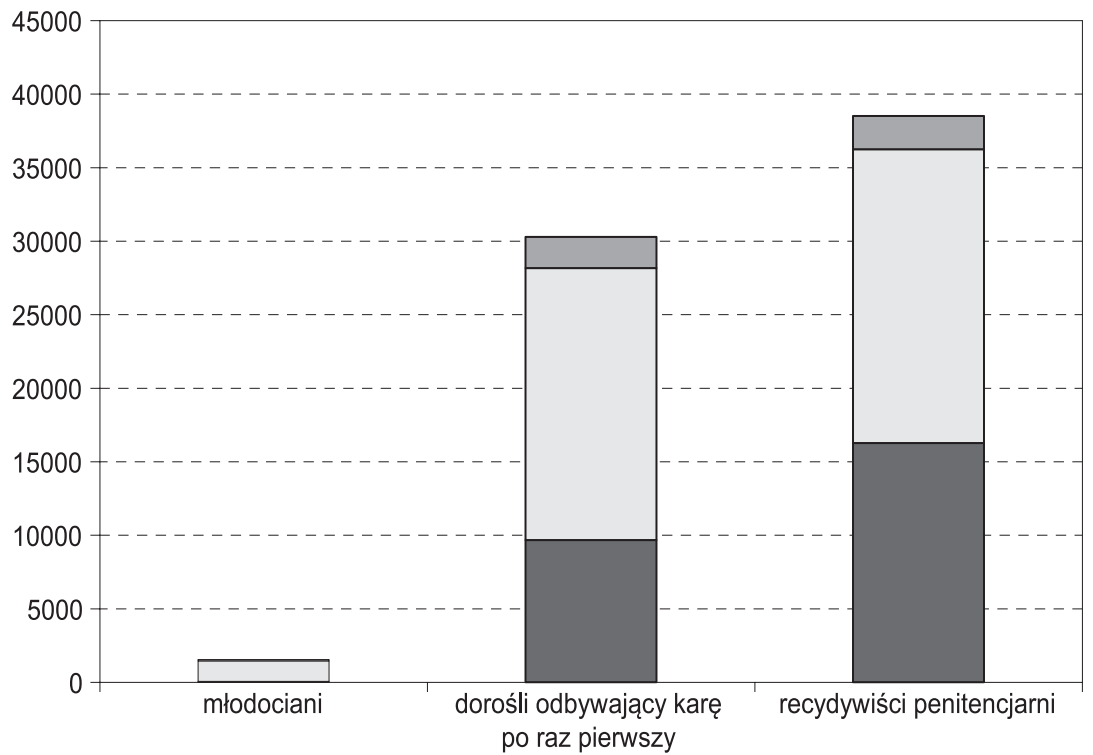

system zwykły $\square$ system programowanego oddziaływania $\square$ system terapeutyczny

Wykres 2. Liczba skazanych i ukaranych odbywających karę w poszczególnych systemach wykonywania kary pozbawienia wolności w dniu 31 grudnia 2014 r.

Źródło: dane statystyczne według „,Rocznej informacji statystycznej za rok 2014” publikowanej przez Centralny Zarząd Służby Więziennej: www.sw.gov.pl (dostęp: 3.01.2016).

\section{Postulowane kierunki reform}

Rezygnacja ze zróżnicowanych rygorów wykonywania kary pozbawienia wolności, które traktowano jako instrument zwiększania dolegliwości kary wykonywanej wobec sprawców uznawanych w określonym kontekście politycznym za niepoprawnych i groźnych, była uzasadniona 
ze względu na nieskuteczność takich rozwiązań dla ograniczania recydywy oraz ich sprzeczność z międzynarodowymi standardami wykonywania kary pozbawienia wolności. We współczesnej penologii niekwestionowaną zasadą traktowania osób pozbawionych wolności jest zasada niezbędności i proporcjonalności restrykcji nakładanych na więźniów. Jest ona wyrażona m.in. w Europejskich Regułach Więziennych ${ }^{45}$, które przewidują, że restrykcje nakładane na osoby pozbawione wolności są ograniczone do niezbędnego minimum i proporcjonalne do uzasadnionego celu, dla którego zostały nałożone (reguła 3). W świetle tego dokumentu życie w więzieniu jest zbliżone, na tyle, na ile to możliwe, do pozytywnych aspektów życia w społeczeństwie (reguła 5). Uzasadnionym celem nakładania na więźniów niezbędnych restrykcji może być realizacja takich zadań personelu więziennego, jak zapewnienie wykonania orzeczonej kary pozbawienia wolności i zastosowanego tymczasowego aresztowania, ułatwianie społecznej integracji więźniów po opuszczeniu zakładu karnego, ochrona społeczeństwa przed sprawcami pozbawionymi wolności przez zapobieganie ich ucieczkom z więzienia czy zapewnienie bezpieczeństwa i uporządkowanego życia wewnątrz więzienia ${ }^{46}$. Restrykcje nie mogą natomiast być legitymizowane dążeniem do osiagnięcia sprawiedliwościowego celu kary pozbawienia wolności, uwzględnianego na etapie jej wymierzania, ponieważ w czasie wykonywania orzeczonej kary jest on realizowany przez samo pozbawienie wolności. Zaostrzanie reżimu więziennego ponad to co jest niezbędne i proporcjonalne dla uzasadnionego celu, aby zwiększyć subiektywnie odczuwaną dolegliwość kary odbywanej przez niektóre kategorie skazanych, nie daje się pogodzić ze współczesnymi standardami traktowania więźniów ${ }^{47}$. Choć potrzeba wyeliminowania rygorów wykonywania kary pozbawienia wolności przewidzianych w poprzednim Kodeksie karnym wykonawczym z 1969 r. nie

45 Rada Europy, Komitet Ministrów, Rekomendacja (2006) 2 Komitetu Ministrów dla państw czlonkowskich Rady Europy, Europejskie Reguty Więzienne, ,Przegląd Więziennictwa Polskiego" 2011, nr 72-73, s. 33 n.

46 Por. Commentary on Recommendation Rec (2006) 2 of the Committee of Ministers to member states on the European Prison Rules, [w:] European Prison Rules, Strasburg 2006, s. 71 n. oraz w tym samym tomie: A. Coyle, Revision of the European Prison Rules, s. $112 \mathrm{n}$.

${ }^{47}$ D. van Zyl Smit, S. Snacken, Principles of European Prison Law and Policy. Penology and Human Rights, New York 2009, s. 81. 
ulega wątpliwości, to jednak nie przesądza ona o tym, że konieczne było wprowadzenie w ich miejsce różnych systemów wykonywania tej kary.

Jednym z powodów wprowadzenia różnych systemów wykonywania kary pozbawienia wolności było dążenie do odrzucenia przymusu resocjalizacji motywowane poszanowaniem praw skazanych i ich podmiotowości. Zasada poszanowania praw skazanych i ich podmiotowości nie wyklucza jednak przygotowania planu wykonywania kary pozbawienia wolności dla skazanego, który nie jest zainteresowany współuczestniczeniem w jego konstruowaniu. Wynika to choćby z Europejskich Reguł Więziennych, którym trudno odmówić przywiązywania należytej wagi do ochrony praw skazanych i ich podmiotowości. Według reguły 103.3 skazanych zachęca się do uczestnictwa w przygotowaniu indywidualnego planu wykonywania kary, jednak taki plan przygotowywany jest dla skazanego rozpoczynającego odbywanie kary także wtedy, kiedy nie chce on brać w tym udziału. Jedynym ograniczeniem jest w tym zakresie długość odbywanej kary; nie ma potrzeby planowania wykonywania kary dla skazanych odbywajacych bardzo krótkie kary. Z wyjątkiem odbywających bardzo krótkie kary, indywidualny plan wykonywania kary pozbawienia wolności oparty na wszechstronnej diagnozie skazanego pozwala na możliwie najlepsze wykorzystanie środków oddziaływania i programów, takich jak zatrudnienie, nauczanie, zajęcia innego rodzaju, interwencje medyczne, psychologiczne i przepustki. Skazani, którzy odmówili uczestniczenia w przygotowaniu takiego planu, po przedstawieniu im planu opracowanego przez administrację zakładu karnego powinni być motywowani do jego realizacji ${ }^{48}$.

W polskich zakładach karnych spory odsetek skazanych odbywa kary do jednego roku pozbawienia wolności. W przypadku takich skazanych przygotowywanie planu wykonywania kary pozbawienia wolności nie wydaje się celowe ze względu na to, że czas ich pobytu w zakładzie karnym nie pozwala na opracowanie i realizację planu obejmującego udział w ustrukturyzowanych programach. Bardziej celowe byłoby opracowanie wkrótce po rozpoczęciu przez nich odbywania kary pozbawienia wolności planu przygotowania ich do zwolnienia. Elementem takiego planu opartego na zdiagnozowaniu skazanego powinno być uświadomienie mu obszarów problemowych sprzyjających recydywie, motywo-

48 Commentary on Recommendation Rec (2006) 2..., s. 96 n. 
wanie go do zmiany w tym zakresie i wskazanie możliwości uzyskania pomocy i wsparcia w wysiłkach zmierzających do zmiany także po zwolnieniu z zakładu karnego. Przygotowanie skazanego do zwolnienia powinno uwzględniać planowanie obowiązków nakładanych na niego na czas próby w okresie warunkowego przedterminowego zwolnienia, ale do tego niezbędna jest zmiana charakteru tej instytucji. Dyskrecjonalne, a w związku z tym nieprzewidywalne warunkowe przedterminowe zwolnienie, utrudnia przygotowanie skazanego do zwolnienia i planowanie oddziaływań na czas próby.

W pracach nad reformą prawa karnego wykonawczego należałoby rozważyć postulat przygotowania planu wykonywania kary pozbawienia wolności — z udziałem skazanego albo bez jego udziału — dla każdego sprawcy odbywającego karę pozbawienia wolności powyżej jednego roku. Plan wykonywania kary powinien obejmować środki istotne dla utrzymania i rozwoju zasobów skazanego (zatrudnienie, podniesienie kwalifikacji zawodowych, przepustki) oraz interwencje korekcyjne zmierzające do eliminowania i ograniczania zdiagnozowanych u niego obszarów problemowych, takich jak uzależnienia, brak kompetencji społecznych, impulsywność, agresywność, przestępcze style myślenia czy pro-przestępcze postawy. Motywowanie skazanych do udziału w oddziaływaniach realizowanych w odpowiedniej sekwencji powinno następować także przez wskazanie im realnego wpływu, jaki ich decyzje w tym zakresie będą miały na zakres ich praw i obowiązków w trakcie odbywania kary oraz perspektywę uzyskania warunkowego przedterminowego zwolnienia na określonych warunkach. W planie wykonywania kary pozbawienia wolności należałoby uwzględnić także umieszczenie skazanego na oddziale terapeutycznym ze względu na potrzebę ochrony jego zdrowia lub umożliwienie udziału w ustrukturyzowanych, profesjonalnych programach terapeutycznych adekwatnych do zdiagnozowanych obszarów problemowych.

Obserwacja praktyki penitencjarnej sugeruje, że przynajmniej do pewnego stopnia zwiększanie odsetka skazanych odbywających karę pozbawienia wolności w systemach terapeutycznym i programowanego oddziaływania stało się celem samym w sobie. Wzrost odsetka skazanych odbywających karę w tych systemach traktowany jest niekiedy jako wskaźnik sukcesu więziennictwa, natomiast pomija się kwestie jako- 
ści prowadzonych oddziaływań i ich skuteczności dla ograniczania przestępczości powrotnej. W dyskusjach nad reformą polityki penitencjarnej jednym z wyjściowych zagadnień powinna być naukowa ocena tego, czy, i na ile, funkcjonowanie trzech różnych systemów wykonywania kary pozbawienia wolności wpływa na realizację indywidualnoprewencyjnego celu wykonywania tej kary.

\section{Enforcement of prison sentences under three systems critical remarks}

\section{Summary}

According to the 1997 Code of Execution of Sentences, prison sentences are enforced in prisons of different kinds and types, and moreover under different systems. In the doctrine of the penal executive law, critical assessment of certain criteria applied while directing prisoners to prisons of appropriate kind and type can be found. However, the need for the operation of prisons differentiated into various kinds and types has not been questioned. The concept of the enforcement of prison sentences under three different systems so far has not been examined in detail, despite the fact that it has been over a dozen years after it was introduced into the penitentiary practice. In this article the origins of differentiated systems of the enforcement of prison sentences will be presented as well as certain controversial aspects of this solution, including: the possibility to implement the therapeutic system outside the therapeutic unit, the unclear differences between the enforcement of prison sentences under the ordinary and programmed treatment system and a high proportion of recidivists serving their sentences under ordinary system without any sentence plan although it is a group of prisoners who have a number of criminogenic needs increasing the risk of re-offending.

Keywords: prison sentence, ordinary system, therapeutic system, programmed treatment system, individual sentence plan. 